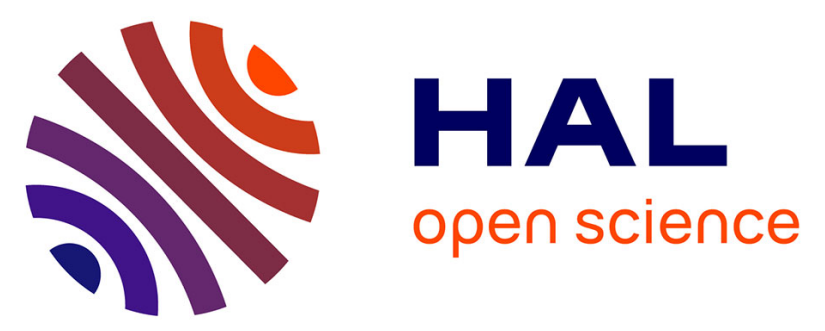

\title{
Development and validation of an UHPLC-MS/MS method for simultaneous quantification of ibrutinib and its dihydrodiol-metabolite in human cerebrospinal fluid.
}

\author{
D Beauvais, Jean-Francois Goossens, Eileen Boyle, B Allal, T Lafont, E \\ Chatelut, Charles Herbaux, Franck Morschhauser, Stéphanie Genay, Pascal \\ Odou, et al.
}

\section{To cite this version:}

D Beauvais, Jean-Francois Goossens, Eileen Boyle, B Allal, T Lafont, et al.. Development and validation of an UHPLC-MS/MS method for simultaneous quantification of ibrutinib and its dihydrodiolmetabolite in human cerebrospinal fluid.. Journal of Chromatography B - Analytical Technologies in the Biomedical and Life Sciences, 2018, Journal of chromatography. B, Analytical technologies in the biomedical and life sciences, 1093-1094, pp.158-166. 10.1016/j.jchromb.2018.06.026 . hal-02178925v2

\author{
HAL Id: hal-02178925 \\ https://hal.univ-lille.fr/hal-02178925v2
}

Submitted on 9 Jun 2021

HAL is a multi-disciplinary open access archive for the deposit and dissemination of scientific research documents, whether they are published or not. The documents may come from teaching and research institutions in France or abroad, or from public or private research centers.
L'archive ouverte pluridisciplinaire HAL, est destinée au dépôt et à la diffusion de documents scientifiques de niveau recherche, publiés ou non, émanant des établissements d'enseignement et de recherche français ou étrangers, des laboratoires publics ou privés. 
1 Development and validation of an UHPLC-MS/MS method for simultaneous quantification of

2 ibrutinib and its dihydrodiol-metabolite in human cerebrospinal fluid.

3 D. Beauvais ${ }^{1,2}$, J-F. Goossens ${ }^{1}$, E. Boyle ${ }^{2}$, B. Allal ${ }^{3}$, T. Lafont ${ }^{3}$, E. Chatelut ${ }^{3}$, C. Herbaux ${ }^{2}$, F. 4 Morschhauser $^{1,2}$, S. Genay ${ }^{1,4}$, P. Odou ${ }^{1,4}$, C. Danel $^{1 *}$

$6{ }^{1}$ Univ. Lille, EA 7365 - GRITA - Groupe de Recherche sur les formes Injectables et les Technologies

7 Associées, F-59000, Lille, France.

$8{ }^{2} \mathrm{CHU}$ Lille, Department of hematology, F-59000, Lille, France. ${ }^{3}$ Institut Claudius-Regaud, IUCT-

9 Oncopole, CRCT, Université de Toulouse, Inserm, Toulouse, France.

$10{ }^{4} \mathrm{CHU}$ Lille, Institut de Pharmacie, F-59000, Lille, France.

Corresponding author:

Dr Cécile Danel

Faculté de pharmacie de Lille - EA 7365 - GRITA

3 rue du Pr Laguesse - 59006 Lille - France

Cecile.danel@univ-lille2.fr - +33 362283026

Keywords:

Ibrutinib ; dihydrodiol-ibrutinib ; LC-MS/MS ; cerebrospinal fluid ; B-cell malignancies

Highlights:

- LC-MS/MS method was validated to quantify ibrutinib and PCI-45227 in CSF

- The biological CSF samples were prepared by a simple and rapid dilution

- The lowest quantifiable ibrutinib concentration in patient's CSF sample is $0.5 \mathrm{ng} / \mathrm{mL}$

- Accuracy profiles were established using the total error approach

- Methods were successfully applied to real human CSF samples 
27 Ibrutinib is an orally administered first-in-class irreversible Bruton's tyrosine kinase (BTK) covalent inhibitor for the treatment of patients with B-cell malignancies. Several isolated clinical observations reported its efficacy in central nervous system dissemination. Herein, we described the development and validation of an ultra-performance liquid chromatography-tandem mass spectrometry (UHPLCMS/MS) procedure for the quantification of ibrutinib and its active metabolite $\mathrm{PCl}-45227$ in cerebrospinal fluid (CSF). This is the first complete validated method for quantification of ibrutinib and PCl-45227 in CSF. The compounds were eluted on a Waters BEH C18 column $(50.0 \times 2.1 \mathrm{~mm} ; 1.7$ $\mu \mathrm{m}$ ) using a gradient elution with a mobile phase composed of ammonium formate buffer $5 \mathrm{mM} \mathrm{pH}$ 3.2 and acetonitrile $+0.1 \%$ formic acid with a flow rate of $400 \mu \mathrm{L} \cdot \mathrm{min}^{-1}$. Two deuterated internal standards were used to obtain the most accurate quantification. The CSF samples were prepared by a simple and rapid dilution. The method was validated by testing the selectivity, response function, intra-day and inter-day precisions, trueness, limits of detection (LOD) and lower limits of quantification (LLOQ). The validation results proved that the methods were suitable to quantify ibrutinib and $\mathrm{PCl}-45227$ in real biological CSF samples from 0.50 (ibrutinib) or 1.00 (PCl-45227) to $30.00 \mathrm{ng} \cdot \mathrm{mL}^{-1}$. Furthermore, the developed method was adapted to allow the quantification of both compounds in plasma and the results were compared to those reported in literature. The plasmatic samples were treated by protein precipitation and the method was validated to quantify ibrutinib and PCl-45227 in real biological plasmatic samples from 5.00 to $491 \mathrm{ng} \cdot \mathrm{mL}^{-1}$. Lastly, for both matrices, accuracy profiles were plotted from the trueness and precision results using a $20 \% \alpha$-risk ( $\beta=80 \%)$ and the tolerance intervals were comprised within the acceptance limits fixed at $\pm 25 \%$ for the LLOQ and $\pm 15 \%$ for the other concentrations. Finally, these methods were successfully applied to quantify ibrutinib and PCl-45227 in real human CSF and plasma samples. 
51

Tyrosine kinase inhibitors (TKI) is a recent pharmaceutical class which has recently undergone an extraordinary development. Several TKI are currently approved at diagnosis of neoplasms or at relapse as monotherapy or combined with chemotherapy or radiotherapy. These inhibitors block abnormally activated signaling pathways essential for cancer cell proliferation thus leading to apoptosis. Ibrutinib is an orally administered first-in-class irreversible Bruton's tyrosine kinase (BTK) covalent inhibitor. BTK is a signaling molecule of the B-cell receptor (BCR) [1] and is needed for abnormal B-lymphocytes to multiply and survive. By blocking BTK, ibrutinib helps move abnormal Blymphocytes out of their nourishing environments in the lymph nodes, bone marrow and other organs [2]. Ibrutinib has been approved by the Food and Drug Administration (FDA) and the European Medicines Agency (EMA) since 2013 or 2014 for the treatment of various B-cell malignancies $[3,4]$ in relapsed/refractory mantle cell lymphoma (MCL) [5], previously untreated with $17 p$ deletion or relapsed/refractory chronic lymphocytic leukemia (CLL) [6,7], relapsed/refractory or unsuitable for immunotherapy Waldenström macroglobulinemia (WM) [8], relapsed/refractory marginal zone lymphoma (MZL) [9] who require systemic therapy.

Central nervous system (CNS) dissemination, except in primary cerebral nervous system lymphoma (PCNSL), is uncommon in B-cell malignancies [10]. It is more frequent at relapse rather than at diagnosis and it is one of the more severe complications because of lack of effective and validated treatment. Efficacy of systemic drugs is limited because of impermeable brain blood-barrier (BBB) [11] and is a cogent area of under-researched application due to CNS dissemination being a common exclusion criterion in clinical studies of ibrutinib. However, many case reports evidenced that ibrutinib crosses the BBB because a complete remission was obtained in various B-cell malignancies [12-17].

The diffusion across the BBB could probably rely on an active influx transport across the BBB or a simple diffusion limited by the high plasma protein binding of ibrutinib. Simultaneous quantification of ibrutinib and its active metabolite, the dihydrodiol-ibrutinib (PCl-45227), in plasma and in CSF would help to establish a pharmacokinetic model in patients with CNS dissemination and could give more information about effects of ibrutinib and its active metabolite on tumoral cells in CSF. Analytical methods for the quantification of ibrutinib and/or PCl-45227 in rat, mouse or human plasma using various extraction procedures (solid-phase extraction, liquid-liquid extraction, protein precipitation) are largely described in literature [18-22]. However, to the best of our knowledge, no method has been specifically developed and validated for quantification of both ibrutinib and $\mathrm{PCl}-$ 45227 in CSF. Some papers reported quantification of ibrutinib [12, 13, 23, 24] and PCl-45227 [15] in both plasma and CSF but very limited information about the analytical method was provided and the 
same method was used for both matrices. Because plasma and CSF are different complex biological matrices and lower concentration are expected in CSF (ibrutinib crosses the BBB with a 1-7\% CSF/plasma ratio $[12,13,15])$, a specific method has to be validated for the quantification of ibrutinib and $\mathrm{PCl}-45227$ in CSF.

Authors described here the development and the validation of a sensitive, selective and rapid UHPLC-MS/MS method for the quantification of ibrutinib and PCI-45227 in human CSF. Since simultaneous quantification in CSF and plasma would be envisaged in a further clinical study, authors have also validated another method in plasma and the results obtained for each matrix are displayed in the paper. Attention was given to the sample preparation specific for each matrix. The method was validated according to the bioanalytical method validation guidelines of French Society of Pharmaceutical Science and Technology (SFSTP) $[25,26]$ and using the accuracy profile approach. Lastly, the applicability of the method to real human CSF samples was studied.

\section{Materials and methods}

\subsection{Chemicals}

Ibrutinib (>99.9\%, MW: 440.5), dihydrodiol-ibrutinib or PCl-45227 (99.1\%, MW: 474.5), $\left[{ }^{2} \mathrm{H}_{5}\right]$-ibrutinib (99.5\%, MW: 445.5) and $\left[{ }^{2} \mathrm{H}_{5}\right]$-dihydrodiol-ibrutinib or $\left[{ }^{2} \mathrm{H}_{5}\right]-\mathrm{PCl}-45227$ (99.5\%, MW: 479.5) were purchased from Alsachim (Strasbourg, France). Methanol and acetonitrile (LC-MS grade) were obtained from Carlo Erba (Val-de-Reuil, France) and formic acid (LC-MS grade) from VWR Chemicals (Fontenay-sous-Bois, France). Ammonium formate (97\%) was supplied by Sigma-Aldrich (SaintQuentin-Fallavier, France). Ultra-pure water was obtained from a Milli-Q purification system (Millipore, Merck, Darmstadt, Germany). Human heparinized plasma was purchased from the Etablissement Français du Sang (EFS) (Rungis, France). One lot of normal human CSF was purchased from Biological Specialty (Colmar, PA, USA). Biological samples of plasma and CSF provided from patients treated in the department of hematology of Lille hospital. The CSF samples provided from 3 patients ( $A, B$ and $C$ ) and the plasmatic samples provided from 3 other patients ( $D, E$ and $F$ ). Signed informed consent was obtained from each patient in accordance with the declaration of Helsinki. Biological samples were stored at $-20^{\circ} \mathrm{C}$ for one month maximum before analyzing. The stability of ibrutinib and $\mathrm{PCl}-45227$ in human plasma at $-20^{\circ} \mathrm{C}$ for 6 months was observed in accordance to de Vries et al. [21].

\subsection{Instrumentation}

The UHPLC system consisted of an Accela pump and a variable loop Accela autosampler (Thermo Fisher Scientific, Waltham, MA, USA). Separations were achieved on a BEH C 18 column (50 x $2.1 \mathrm{~mm}$; 
$1.7 \mu \mathrm{m})$ connected to a BEH $C_{18}$ Vanguard pre-column $(5 \times 2.1 \mathrm{~mm} ; 1.7 \mu \mathrm{m})$ (Waters, Guyancourt, France) with a mobile phase composed of ammonium formate buffer $5 \mathrm{mM} \mathrm{pH} 3.2$ (solvent A) and acetonitrile $+0.1 \%$ formic acid (solvent $B$ ) using the following gradient elution: 0-3.5 min, linear increase to $5 \%$ solvent $A$ and $95 \%$ solvent $B ; 3.5-4.5 \mathrm{~min}, 5 \%$ solvent $A$ and $95 \%$ solvent $B ; 4.5-6.0$ min, linear decrease to $95 \%$ solvent $A$ and $5 \%$ solvent $B ; 6.0-8.0$ min, $95 \%$ solvent $A$ and $5 \%$ solvent $B$ for re-equilibration of the column. The flow rate was $400 \mu \mathrm{L} \cdot \mathrm{min}^{-1}$ and the oven temperature was $30^{\circ} \mathrm{C}$. Ten $\mu \mathrm{L}$ of the samples were injected via the loop injection system and the flush syringe was washed with a strong acidic solution ( $50 \%$ acetonitrile and $50 \%$ formic acid, $0.35 \mathrm{M}$ ) between injections. The temperature of the autosampler was set at $10^{\circ} \mathrm{C}$. The UHPLC system was coupled to a Vantage triple quadripole mass spectrometer controlled by the Xcalibur ${ }^{\circledR}$ software (Thermo Fisher Scientific, Waltham, MA, USA). All experiments were acquired using positive electrospray ionization $(E S I+)$. MS-MS parameters were optimized via the direct infusion of each analyte $\left(5 \mu \mathrm{g} \cdot \mathrm{mL}^{-1}\right.$ in methanol) applying a flow rate of $400 \mu \mathrm{L} \cdot \mathrm{min}^{-1}$ of the mobile phase ( $95 \%$ solvent A and $5 \%$ solvent B). Optimal parameters were as follows: capillary voltage, $3 \mathrm{kV}$; capillary temperature, $324^{\circ} \mathrm{C}$; desolvation temperature, $371^{\circ} \mathrm{C}$; sheath gas, $40 \mathrm{PSI}$; auxiliary gas, $55 \mathrm{PSI}$; sweep gas flow $\left(\mathrm{N}_{2}\right), 60 \mathrm{~L} . \mathrm{h}^{-}$ ${ }^{1}$. Argon was used as the collision gas at a pressure of $1.0 \mathrm{mTor}$. Optimized S-lens were $140 \mathrm{~V}$ for ibrutinib and its internal standard and $120 \mathrm{~V}$ for $\mathrm{PCl}-45227$ and its internal standard. Experiments were performed using the multiple reaction monitoring (MRM). Two transitions for each compound were chosen, the first transition was used for quantification and the second one for confirmation. Table 1 summarizes the MRM acquisitions parameters. The eluent from the first two minutes of the run was diverted to the waste (divert valve mode) to protect the mass spectrometer from the early eluting matrix components.

\subsection{Solutions}

Stock solutions of ibrutinib, $\mathrm{PCl}-45227,\left[{ }^{2} \mathrm{H}_{5}\right]$-ibrutinib and $\left[{ }^{2} \mathrm{H}_{5}\right]-\mathrm{PCl}-45227$ were individually prepared at $1.00 \mathrm{~g} . \mathrm{L}^{-1}$ in methanol, and stored at $-20^{\circ} \mathrm{C}$.

\subsubsection{Cerebrospinal fluid}

\subsubsection{Standard solutions}

Calibration standards (CS) and validation standards (VS) were prepared by serial dilutions from separated stock solutions on three successive days. Samples were prepared by adding a constant CSF volume chosen according to the preparation of the biological samples. A solution containing both internal standards at $8.00 \mathrm{ng} \cdot \mathrm{mL}^{-1}$ was prepared in methanol. A solution containing both ibrutinib and PCl-45227 was prepared at $6.00 \mathrm{ng} \cdot \mathrm{mL}^{-1}$ in methanol. Two hundred $\mu \mathrm{L}$ of each CS and VS solutions 
were prepared by adding $20 \mu \mathrm{L}$ of blank CSF, $50 \mu \mathrm{L}$ of the internal standards solution at $8.00 \mathrm{ng} \cdot \mathrm{mL}^{-1}$, a variable volume of the solution containing both analytes at $6.00 \mathrm{ng} \cdot \mathrm{mL}^{-1}$ and a variable volume of methanol to reach $200 \mu \mathrm{L}$. Finally, the concentration of both internal standards was $2 \mathrm{ng} \cdot \mathrm{mL}^{-1}$ in all solutions. Eight calibration standards were prepared with concentrations of ibrutinib and $\mathrm{PCl}-45227$ at $0.05,0.10,0.20,0.60,1.20,1.80,2.40$ or $3.00 \mathrm{ng} . \mathrm{mL}^{-1}$. The validation standards were prepared at four concentration levels: 0.05 (low VS 1 ), 0.10 (low VS 2 ), 1.20 (medium VS) and 3.00 (high VS) ng. $\mathrm{mL}^{-1}$. All these solutions were prepared each day ( 3 days) with four replicates per day for each VS ( $n=12$ ).

\subsubsection{Sample preparation}

The method consisted in a simple dilution of the CSF matrix. For the CS and VS samples, the solutions (200 $\mu \mathrm{L}$ which contained $20 \mu \mathrm{L}$ of blank CSF) were evaporated under nitrogen flow at $45^{\circ} \mathrm{C}$ and the residues were reconstituted in $60 \mu \mathrm{L}$ of a 70:30 - acetonitrile:ammonium formate buffer mixture. Thus, the initial salts concentration in the CSF was diluted with a dilution factor equal to 3 . Then, 10 $\mu \mathrm{L}$ were immediately injected in the chromatographic system. Thus, analyzed concentrations of ibrutinib and $\mathrm{PCl}-45227$ in the CS samples were $0.17,0.33,0.67,2.00,4.00,6.00,8.00$ and 10.00 ng. $\mathrm{mL}^{-1}$ and analyzed concentrations of ibrutinib and PCl-45227 in the VS samples were $0.17,0.33$, 4.00 and $10.00 \mathrm{ng} \cdot \mathrm{mL}^{-1}$. The concentration of both internal standards was $6.67 \mathrm{ng} \cdot \mathrm{mL}^{-1}$ in all samples.

For the biological CSF samples, in order to strictly respect the protocol used for the standard samples, $50 \mu \mathrm{L}$ of the internal standard solutions at $8.00 \mathrm{ng} \cdot \mathrm{mL}^{-1}$ and $130 \mu \mathrm{L}$ of methanol were added to $20 \mu \mathrm{L}$ of the biological sample and prepared solutions were evaporated under nitrogen flow at $45^{\circ} \mathrm{C}$. Residues were reconstituted in $60 \mu \mathrm{L}$ of a 70:30 (v/v) - acetonitrile: ammonium formate buffer mixture. Then, $10 \mu \mathrm{L}$ were immediately injected in the chromatographic system.

\subsubsection{Plasma}

\subsubsection{Standard solutions}

Calibration standards (CS) and validation standards (VS) samples were prepared by serial dilutions from separated stock solutions on three successive days. All solutions were prepared by dilution in blank plasma. A solution containing both internal standards at $80.0 \mathrm{ng} \cdot \mathrm{mL}^{-1}$ was prepared in acetonitrile by dilution of both methanolic stock solutions at $1.00 \mathrm{~g} . \mathrm{L}^{-1}$. This solution was stored at $20^{\circ} \mathrm{C}$ before use. A solution containing both ibrutinib and PCl-45227 in plasma at $5000 \mathrm{ng} \cdot \mathrm{mL}^{-1}$ was used to prepare seven calibration standards. Final concentrations of ibrutinib and $\mathrm{PCl}-45227$ were: 5.0, 50.0, 125.0, 259.5, 345.3, 429.6 and $491.0 \mathrm{ng} \cdot \mathrm{mL}^{-1}$. The VS were prepared three concentration levels: 5.0 (low VS), 259.5 (medium VS) and 491.0 (high VS) ng. $\mathrm{mL}^{-1}$. All these solutions were 
prepared each day ( 3 days) with four replicates per day for each VS ( $n=12)$. Internal standards were added during the following sample preparation step.

\subsubsection{Sample preparation}

Samples were pretreated by protein precipitation. Sixty $\mu \mathrm{L}$ of each earlier prepared CS and VS solutions were mixed with $180 \mu \mathrm{L}$ of the solution containing the internal standards at $80.0 \mathrm{ng} \cdot \mathrm{mL}^{-1}$ and the solutions were vortexed for $20 \mathrm{~s}$. After centrifugation at $13000 \mathrm{~g}$ for 10 minutes at $4^{\circ} \mathrm{C}$, supernatants $(195 \mu \mathrm{L})$ were removed and evaporated under nitrogen flow at $45^{\circ} \mathrm{C}$. Residues were reconstituted in $120 \mu \mathrm{L}$ of a 70:30 (v/v) - acetonitrile: ammonium formate buffer mixture. Then, 10 $\mu \mathrm{L}$ were immediately injected in the chromatographic system. Thus, analyzed concentrations of ibrutinib and PCl-45227 in the CS samples were 2.0, 20.3, 50.8, 105.4, 140.3, 174.5 and $199.5 \mathrm{ng}^{\mathrm{mL}}{ }^{-1}$ and analyzed concentrations of ibrutinib and PCl-45227 in the VS were 2.0, 105.4 and $199.5 \mathrm{ng} . \mathrm{mL}^{-1}$. The concentration of both internal standards was $97.5 \mathrm{ng} \cdot \mathrm{mL}^{-1}$ in all samples.

For the biological plasmatic samples, in order to strictly respect the protocol used for the standard samples, $60 \mu \mathrm{L}$ of the biological sample were mixed with $180 \mu \mathrm{L}$ of a frozen solution containing the internal standards at $80.0 \mathrm{ng} . \mathrm{mL}^{-1}$ and the solutions were vortexed for $20 \mathrm{~s}$. After centrifugation at $13000 \mathrm{~g}$ for 10 minutes at $4^{\circ} \mathrm{C}$, supernatants $(195 \mu \mathrm{L})$ were removed and evaporated under nitrogen flow at $45^{\circ} \mathrm{C}$. Residues were reconstituted in $120 \mu \mathrm{L}$ of a 70:30 (v/v) - acetonitrile: ammonium formate buffer mixture. Then, $10 \mu \mathrm{L}$ were immediately injected in the chromatographic system.

\subsection{Validation procedure}

The whole method validation procedure was based on SFSTP requirements [25-26]. Selectivity, response function, precision (intra-day and inter-day precision), trueness, limits of detection (LOD) and lower limit of quantification (LLOQ) were studied. The validation was carried out on three consecutive days. Each day, a series of eight (for CSF) or seven (for plasma) calibrations of standards, four (for CSF) or three (for plasma) VS (four replicates each day), a single blank and a double blank were prepared and analyzed. The acceptance criteria for precision and trueness were fixed in accordance with the requirements of the SFSTP which recommends relative standard deviation (RSD) and relative bias under $15 \%$ for the VS samples (20\% for the LLOQ). Lastly, accuracy profiles were established from the trueness and precision results. Accuracy profiles were plotted using a $20 \% \alpha$-risk $(\beta=80 \%)$. Acceptance limits were fixed at $\pm 25 \%$ for the LLOQ and $\pm 15 \%$ for the other concentrations.

\section{Results and discussion}




\subsubsection{MS/MS detection}

212 To optimize the detection parameters, each compound was infused and ionized by positive ESI. The 213 predominantly signals corresponding to the $[\mathrm{M}+\mathrm{H}]^{+}$precursor ions were observed at $\mathrm{m} / \mathrm{z} 441.3$ 214 (ibrutinib), $446.3\left(\left[{ }^{2} \mathrm{H}_{5}\right]-\right.$ ibrutinib), 475.5 (PCl-45227) and $\left.480.5\left({ }^{2} \mathrm{H}_{5}\right]-\mathrm{PCl}-45227\right)$. After optimization of the MS/MS parameters (collision energy in particular), the most abundant product ions were 138.0 (ibrutinib), $138.0\left(\left[{ }^{2} \mathrm{H}_{5}\right]\right.$-ibrutinib), 304.3 (PCl-45227) and $309.3\left(\left[{ }^{2} \mathrm{H}_{5}\right]-\mathrm{PCl}-45227\right)$, and were chosen as quantifier ions. Results were in accordance with the fragmentations described by previous reports $[19,20]$. Fragmentation patterns of ibrutinib and PCI-45227 are displayed in figure 1.

\subsubsection{Chromatography}

220

The chromatographic conditions were optimized to obtain a sufficient resolution between ibrutinib and $\mathrm{PCl}-45227$ in a short analysis time using a $\mathrm{C}_{18}$ stationary phase. The mobile phase composition was selected considering the results displayed in various papers dealing with the analysis of ibrutinib $[18,20]$. Acetonitrile was preferred to methanol due to the highest sensitivity, best peak shape and resolution. Aqueous mobile phase was composed of a $5 \mathrm{mM}$ ammonium formate buffer with $\mathrm{pH}$ adjusted to 3.2 . Formic acid $0.1 \%$ was added to the mobile phase in order to increase the protonation of analytes and then to enhance the response of analytes [18, 20]. After optimization of the gradient program, retention times of ibrutinib and $\mathrm{PCl}-45227$ were 3.1 and 2.7 minutes, respectively, and the resolution was 3.2. The total run-time was 8 minutes allowing a slight return to the initial mobile phase composition and column equilibration. The optimal chromatogram obtained is displayed in figure 2.

\subsubsection{Matrix effect}

Preliminary study of the matrix effect was performed for CSF and plasma at two concentration levels (medium and high-VS concentrations) for ibrutinib and PCl-45227. Matrix effects were calculated from the ratio of the peak area ratio in presence of matrix to the peak area ratio in the absence of matrix (neat solvents: methanol for CSF and acetonitrile for plasma). For CSF, large matrix effects were pointed out since they were between $-3 \%$ and $-37 \%$. For plasma, they were between $-7 \%$ and $+18 \%$. These results were sufficient to impose the preparation of all standards samples (CS and VS) using blank matrices (CSF or plasma) and not the neat solvents.

\subsubsection{Sample preparation}


Taking into account the own characteristics of the CSF and plasma matrices, sample preparations

241 peculiar to each matrix were developed.

242 The CSF is nearly protein-free compared with plasma but contains high salt concentrations which can result in ionic suppression in LC-MS/MS analysis. Since the expected concentrations in CSF biological samples were largely lower than those expected in plasma, particular attention must be paid to this problem and the sample preparation had to reduce salt concentrations. Protein precipitation was not adapted. In literature, when a sample preparation method is reported for this specific matrix, liquidliquid extraction (LLE) is commonly described [27-31]. The preparation of CSF samples using dilution is reported in few studies with dilution factors between 4 and 10 [31-33]. The few studies that report ibrutinib quantification in CSF referred to the method described for plasma i.e. protein precipitation [19] or no information is given [15]. Authors choose to use dilution since it avoids the low recovery usually reported using LLE and reduces the preparation time. A dilution factor equal to 3 resulted from a compromise between the necessary dilution of salts and the undesired diminution of the analyte concentrations and it fulfilled our goal of being able to quantify ibrutinib and $\mathrm{PCl}-45227$ in biological samples until 0.50 or $1.00 \mathrm{ng} \cdot \mathrm{mL}^{-1}$. For the plasma, the removal of proteins prior to injection is necessary to preserve the integrity of the chromatographic system. Numerous studies have reported methods such as solid phase extraction, liquid-liquid extraction or protein precipitation for quantification of ibrutinib in plasma [18-22]. Here, precipitation was chosen since this methodology is simple, fast and provides relatively high recovery.

\subsection{Method validation}

\subsubsection{Selectivity}

262 Method selectivity was studied by analyzing blank CSF and plasma samples $(n=4)$. Single blanks 263 (spiked with the internal standards) and double blanks (unspiked) were prepared as described in the 264 experimental sections 2.3 .1 and 2.3.2. The selectivity of the method was demonstrated by comparing 265 the chromatograms obtained for the blank samples with those for the corresponding standard spiked samples. Two MRM transitions were monitored for each analyte and no interfering peaks were detected at the retention times of the analytes and internal standards. The results suggested that no endogenous component from the CSF and plasma matrix interfered with the measurement of the analytes demonstrating the selectivity of the method.

\subsubsection{Response function}


271 Calibration curves were based on the peak area ratio of the analyte to its internal standard. The

272 regression model showing the best results for precision and trueness (for the VS samples) was 273 chosen. For both analytes and both matrices, the best calibration model was obtained for the weighted $1 / x$ quadratic regression. Standard curves exhibited excellent determination coefficient $\left(r^{2}>0.999\right)$ in the range $0.17 \mathrm{ng} \cdot \mathrm{mL}^{-1}-10.00 \mathrm{ng} \cdot \mathrm{mL}^{-1}$ for analyzed CSF samples and in the range $2.00-$ $199.50 \mathrm{ng} \cdot \mathrm{mL}^{-1}$ for analyzed plasma samples

\subsubsection{Precision and trueness}

Precision (intra-day and inter-day precision) and trueness were determined from 4 replicates at 4 (for CSF) or 3 (for plasma) VS concentrations over 3 days ( $n=12$ for each concentration). Imprecisions were expressed as RSD of the ratio of the standard deviation on the theoretical value at each concentration level. Trueness was evaluated by comparing the nominal and back-calculated concentrations and was expressed as \% relative bias. Validation parameters are displayed in Tables 2 and 3 for the quantification in CSF and in plasma, respectively. In CSF, the intra-day precision (RSD) ranged from $1.6 \%$ to $8.6 \%$ for ibrutinib and from $3.4 \%$ to $33.3 \%$ for $\mathrm{PCl}-45227$. The inter-day precision (RSD) ranged from $2.1 \%$ to $19.7 \%$ for ibrutinib and from $5.0 \%$ to $40.1 \%$ for $\mathrm{PCl}-45227$. The trueness (relative bias) ranged from $-14.0 \%$ to $+4.6 \%$ for ibrutinib and from $-5.8 \%$ to $+16.0 \%$ for $\mathrm{PCl}-$ 45227. Thus, for ibrutinib, all validation parameters on precision and trueness were under $20 \%$ at the low $\mathrm{VS}_{1}$ and under $15 \%$ for other VS. For PCl-45227, the validation parameters obtained for the low $\mathrm{VS}_{1}$ exceeded the allowed limits of $20 \%$ but were acceptable for the low $\mathrm{VS}_{2}$, medium and high VS. In plasma, the intra-day precision ranged from $2.0 \%$ to $10.6 \%$ for ibrutinib and from $2.7 \%$ to $8.8 \%$ for $\mathrm{PCl}-45227$. The inter-day precision ranged from $2.6 \%$ to $10.6 \%$ for ibrutinib and from $4.4 \%$ to $8.8 \%$ for $\mathrm{PCl}-45227$. The trueness ranged from $+0.3 \%$ to $+6.2 \%$ for ibrutinib and from $-2.8 \%$ to $+0.2 \%$ for $\mathrm{PCl}-45227$. Thus, these validation parameters on precision and trueness obtained in plasma were acceptable. It is worth mentioning that values obtained for the medium and high VS concentrations are, in all cases, lower than those obtained for the low VS concentrations.

\subsubsection{Limits of detection and quantification}

The limit of detection (LOD) was defined by the concentration for which the signal-to-noise ratio was 3. For ibrutinib and PCl-45227, LOD were estimated to be 0.01 and $0.03 \mathrm{ng} \cdot \mathrm{mL}^{-1}$, respectively. The lower limits of quantification (LLOQ), defined as the lowest concentration of analyte which can be quantified reliably, were set at the lowest VS concentrations with acceptable precision and trueness (RSD and relative bias $<20 \%$ ). For quantification in CSF, the low VS concentrations were $0.17 \mathrm{ng} \cdot \mathrm{mL}^{-1}$ 302 (low VS ${ }_{1}$ ) for ibrutinib and $0.33 \mathrm{ng} \cdot \mathrm{mL}^{-1}($ low VS 2 ) for PCl-45227. For quantification in plasma, LLOQ of $3032.00 \mathrm{ng} \cdot \mathrm{mL}^{-1}$ were defined for ibrutinib and $\mathrm{PCl}-45227$. Thus, taking into account the preparation of 
the biological samples, the developed method is suitable to quantify ibrutinib and $\mathrm{PCl}-45227$ from 0.50 (ibrutinib) or $1.00 \mathrm{ng} \cdot \mathrm{mL}^{-1} \mathrm{PCl}-45227$ ) in CSF and from $5.0 \mathrm{ng} \cdot \mathrm{mL}^{-1}$ in plasma. Indeed, in CSF, for ibrutinib, the LLOQ was $0.17 \mathrm{ng} \cdot \mathrm{mL}^{-1}$ in the analyzed sample which corresponds to $0.50 \mathrm{ng} \cdot \mathrm{mL}^{-1}$ in the biological sample; for $\mathrm{PCl}-45227$, the LLOQ was $0.33 \mathrm{ng} \cdot \mathrm{mL}^{-1}$ in the analyzed sample which corresponds to $1.00 \mathrm{ng} \cdot \mathrm{mL}^{-1}$ in the biological sample. In plasma, the LLOQ were $2.00 \mathrm{ng} \cdot \mathrm{mL}^{-1}$ for both analytes in the analyzed sample which corresponds to $5.00 \mathrm{ng} \cdot \mathrm{mL}^{-1}$ in the biological sample.

\subsubsection{Accuracy profiles}

The accuracy was based on the total error approach taking into account the precision and trueness of the method. Accuracy profiles are displayed in figure 3 . Whatever the analyte (ibrutinib or PCl45227), the tolerance intervals were comprised within the acceptance limits at the various VS concentrations in the two matrices. Therefore, for CSF, the method was validated on the whole range between 0.17 (ibrutinib) or 0.33 ( $\mathrm{PCl}-45227$ ) and $10.00 \mathrm{ng} \cdot \mathrm{mL}^{-1}$. Taking into account the preparation of the biological CSF samples, the developed method is suitable to quantify ibrutinb from 0.50 to 30 ng. $\mathrm{mL}^{-1}$ and PCl-45227 from 1.00 to $30 \mathrm{ng} \cdot \mathrm{mL}^{-1}$ in the collected CSF samples. For plasma, the method was validated on the whole range between 2.00 and $199.50 \mathrm{ng} \cdot \mathrm{mL}^{-1}$. Taking into account the preparation of the biological plasmatic samples, the developed method is suitable to quantify both compounds from 5.0 to $491.0 \mathrm{ng} \cdot \mathrm{mL}^{-1}$ in the collected plasmatic samples.

\subsection{Applicability to biological samples}

The suitability of the developed method was studied for the quantification of ibrutinib and PCI-45227 in CSF and plasma samples obtained from patients with various B-cell malignancies and treated with $420 \mathrm{mg}$ per day of ibrutinib. Samples were taken more than 4 hours after administration. Three samples were analyzed for each matrix. Figure 4 presents the chromatograms obtained for double blank, blank spiked at the LLOQ and patients for Ibrutinib and PCI-45227 in both matrices. The concentrations of ibrutinib and $\mathrm{PCl}-45227$ determined in the CSF and plasmatic patients' samples are displayed in Table 4. CSF concentrations ranged between 0.59 and $2.95 \mathrm{ng} \mathrm{mL}^{-1}$ for ibrutinib, and 1.45 and $9.73 \mathrm{ng} \cdot \mathrm{mL}^{-1}$ for $\mathrm{PCl}-45227$. Plasma concentrations ranged between 6.61 and $19.44 \mathrm{ng} \cdot \mathrm{mL}^{-1}$ for ibrutinib, and 12.00 and $47.89 \mathrm{ng} \cdot \mathrm{mL}^{-1}$ for PCl-45227. These results were consistent with the few previously published data for quantification of ibrutinib and $\mathrm{PCl}-45227$ reported in CSF and in plasma with a $1-7 \% \mathrm{CSF} /$ plasma ratio $[12,13]$. Moreover, these results show for the first time that $\mathrm{PCI}-45227$ is found in CSF. Interestingly, as described in literature for plasmatic concentrations of both analytes $[34,35]$, concentrations are higher for PCl-45227 than for ibrutinib in CSF. 
4. Conclusion

338 We developed a performant UHPLC-MS/MS method for the simultaneous quantification of ibrutinib 339 and $\mathrm{PCl}-45227$, its active metabolite, in CSF and in plasma. Attention was given to the sample 340 preparation which needs to be developed for each matrix: dilution for CSF and protein precipitation 341 for plasma. The method was validated according to the current SFSTP requirements and was successfully applied to quantify ibrutinib and $\mathrm{PCl}-45227$ in human CSF and plasma samples from patients. To the best of our knowledge, this is the first study reporting validated quantification of ibrutinib and PCl-45227 in CSF.

Ibrutinib is a relatively recent drug and additional therapeutic indications are yet in current development. Several isolated clinical observations reported its efficacy in CNS dissemination of various B-cell malignancies, which were excluded in the large cohort studies. This combined method of quantification in CSF and in plasma could support pharmacokinetic studies of ibrutinib and PCI45227 in the future. A best knowledge of diffusion and metabolism into the CNS could help to predict efficacy of ibrutinib in the CNS dissemination, a rare but serious complication of B-cell malignancies. Simultaneous quantification of ibrutinib and its metabolite PCl-45227 in CSF and in plasma would help establishing a pharmacokinetic model in patients with CNS dissemination and could give more information about effects of ibrutinib and its active metabolite on tumoral cells in CSF. 


\section{References}

[1] Z. Pan , H. Scheerens, S.J. Li, B.E Schultz, P.A. Sprengeler, L.C. Burrill, R.V. Mendonca, M.D. Sweeney, K.C. Scott, P.G. Grothaus, D.A. Jeffery, J.M. Spoerke, L.A. Honigberg, P.R. Young, S.A. Dalrymple, J.T. Palmer, Discovery of selective irreversible inhibitors for Bruton's tyrosine kinase, Chem. Med. Chem. 2 (2007) 58-61.

[2] Patient Resources \& Information for IMBRUVICA ${ }^{\circledast}$ (ibrutinib). http://www.imbruvica.com/ (accessed 07 May 2018).

[3] Development history and FDA approval process for Imbruvica. http://www.drugs.com/history/imbruvica.html (accessed 07 May 2018)

[4] Imbruvica - Authorisation details. http://www.ema.europa.eu/ema/index.jsp?curl=pages/medicines/human/medicines/003791/huma n med 001801.jsp\&mid=WC0b01ac058001d124 (accessed 07 May 2018)

[5] M. Dreyling, W. Jurczak, M. Jerkeman, R.S. Silva, C. Rusconi, M. Trneny, F. Offner, D. Caballero, C. Joao, M. Witzens-Harig, G. Hess, I. Bence-Bruckler, S.G. Cho, J. Bothos, J.D. Goldberg, C. Enny, S. Traina, S. Balasubramanian, N. Bandyopadhyay, S. Sun, J. Vermeulen, A. Rizo, S.Rule, Ibrutinib versus temsirolimus in patients with relapsed or refractory mantle-cell lymphoma: an international, randomised, open-label, phase 3 study, Lancet 387 (2016) 770-778.

[6] J.C. Byrd, J.R.Brown, S. O’Brien, J.C. Barrientos, N.E. Kay, N.M. Reddy, S. Coutre, C.S. Tam, S.P. Mulligan, U. Jaeger, S. Devereux, P.M. Barr, R.R. Furman, T.J. Kipps, F. Cymbalista, C. Pocock, P. Thornton, F. Caligaris-Cappio, T. Robak, J. Delgado, S.J. Schuster, M. Montillo, A. Schuh, S. de Vos, D. Gill, A. Bloor, C. Dearden, C. Moreno, J.J. Jones, A.D. Chu, M. Fardis, J. McGreivy, F. Clow, D.F. James, P. Hillmen, Ibrutinib versus ofatumumab in previously treated chronic lymphoid leukemia, N. Engl. J. Med. 371 (2014) 213-23.

[7] J.A. Burger, A.Tedeschi, P.M. Barr, T.Robak, C. Owen, P. Ghia, O. Bairey, P. Hillmen, N.L. Bartlett , J. Li, D. Simpson, S. Grosicki, S. Devereux, H. McCarthy, S. Coutre, H. Quach, G. Gaidano, Z. Maslyak, D.A. Stevens, A. Janssens, F. Offner, J. Mayer, M. O'Dwyer, A. Hellmann, A. Schuh, T. Siddiqi, A. Polliack, C.S. Tam, D. Suri, M. Cheng, F. Clow, L. Styles, D.F. James, T.J. Kipps, Ibrutinib as initial therapy for patients with chronic lymphocytic leukemia, N. Engl. J. Med. 373 (2015) 2425-2437.

[8] M.A. Dimopoulos, J. Trotman, A. Tedeschi, J.V. Matous, D. Macdonald, C. Tam, O.Tournilhac, S. Ma, A. Oriol, L.T. Heffner, C. Shustik, R. García-Sanz, R.F. Cornell, C. Fernández de Larrea, J.J. Castillo, 
401

402

403

404

405

406

407

408

409

410

411

412

413

414

415

416

417

418

419

420

421

422

423

424

425

426

427

428

429

430

431

432

433

434

M. Granell, M.A. Kyrtsonis, V. Leblond, A. Symeonidis, E. Kastritis, P. Singh, J. Li, T. Graef, E.Bilotti, S. Treon, C. Buske, Ibrutinib for patients with rituximab-refractory Waldenström's macroglobulinaemia (iNNOVATE): an open-label substudy of an international, multicentre, phase 3 trial, Lancet Oncol. 18 (2017) 241-250.

[9] A. Noy, S. de Vos, C. Thieblemont, P. Martin, C.R. Flowers, F. Morschhauser, G.P. Collins, S.Ma, M. Coleman,S. Peles, S. Smith, J.C. Barrientos, A. Smith, B. Munneke, I. Dimery, D.M. Beaupre, R.Chen, Targeting Bruton tyrosine kinase with ibrutinib in relapsed/refractory marginal zone lymphoma, Blood 129 (2017) 2224-2232.

[10] S.H. Bernstein, J.M. Unger, M. Leblanc, J. Friedberg, Miller TP, Fisher RI, Natural history of CNS relapse in patients with aggressive non-Hodgkin's lymphoma: a 20-year follow-up analysis of SWOG 8516, J. Clin. Oncol. 27 (2009) 114-119.

[11] R. Nau, F. Sörgel, H. Eiffert, Penetration of drugs through the blood-cerebrospinal fluid/bloodbrain barrier for treatment of central nervous system infections, Clin. Microbiol. Rev. 23 (2010) 858883.

[12] S. Bernard, L. Goldwirt, S. Amorim, P. J. Brière, E. de Kerviler, S. Mourah, H. Sauvageon, C. Thieblemont, Activity of ibrutinib in mantle cell lymphoma patients with central nervous system relapse, Blood 126 (2015) 1695-1698.

[13] A. Cabannes-Hamy, R. Lemal, L. Goldwirt, S. Poulain, S Amorin, R. Perignon, J. Berger, P. Brice, E. De Kerviler, J.O. Bay, H. Sauvageon, K. Beldjord, S. Mourah, O. Tournilhac, C. Thieblemont, Efficacy of ibrutinib in the treatment of Bing-Neel syndrome, Am. J. Hematol. 91 (2016) 17-19.

[14] D.L. Tucker, G. Naylor, A. Kruger, M.S. Hamilton, G. Follows, S.A. Rule, Ibrutinib is a safe and effective therapy for systemic mantle cell lymphoma with central nervous system involvement - a multi-centre case series from the United Kingdom, Br. J. Haematol. 178 (2017) 327-329.

[15] C. Mason, S. Savona, J.N. Rini, J.J. Castillo, L. Xu, Z.R. Hunter, S.P. Treon, S.L. Allen, Ibrutinib penetrates the blood brain barrier and shows efficacy in the therapy of Bing Neel syndrome, Br. J. Haematol. 179 (2017) 339-341. 
[16] A. Wanquet, R. Birsen, R. Lemal, M. Hunault, V. Leblond, T. Aurran-Schleinitz, Ibrutinib responsive central nervous system involvement in chronic lymphocytic leukemia, Blood 127 (2016) 2356-2358.

[17] L.S. Hiemcke-Jiwa, R.J. Leguit, J.H. Radersma-van Loon, P.E. Westerweel, J.J.M. Rood, J.K. Doorduijn, M.M.H. Huibers, M.C. Minnema, Efficacy of ibrutinib in a patient with transformed lymphoplasmacytic lymphoma and central nervous system involvement, Leuk. Lymphoma (2017) 14.

[18] S. Veeraraghavan, S. Viswanadha, S.Thappali, B. Govindarajulu, S. Vakkalanka, M. Rangasamy, Simultaneous quantification of lenalidomide, ibrutinib and its active metabolite $\mathrm{PCl}-$ 45227 in rat plasma by LC-MS/MS: application to a pharmacokinetic study, J. Pharm. Biomed. Anal. 107 (2015) 151-158.

[19] J.J.M. Rood, S. van Hoppe, A.H. Schinkel, J.H.M. Schellens, J.H. Beijnen, R.W. Sparidans, Liquid chromatography-tandem mass spectrometric assay for the simultaneous determination of the irreversible BTK inhibitor ibrutinib and its dihydrodiol-metabolite in plasma and its application in mouse pharmacokinetic studies, J. Pharm. Biomed. Anal. 118 (2016) 123-131.

[20] H.H. Huynh, C. Pressiat, H. Sauvageon H,I. Madelaine, P. Maslanka, C. Lebbé, C. Thieblemont, L. Goldwirt, S. Mourah, Development and Validation of a Simultaneous Quantification Method of 14 Tyrosine Kinase Inhibitors in Human Plasma Using LC-MS/MS, Ther. Drug Monit . 39 (2017) 43-54.

[21] R. de Vries, M. Huang, N. Bode, P. Jejurkar, J. Jong, J. Sukbuntherng, L. Sips, N. Weng, P. Timmerman, T. Verhaeghe, Bioanalysis of ibrutinib and its active metabolite in human plasma: selectivity issue, impact assessment and resolution, Bioanalysis 7 (2015) 2713-2724.

[22] M. Fouad, M. Helvenstein, B. Blankert, Ultra High Performance Liquid Chromatography Method for the Determination of Two Recently FDA Approved TKIs in Human Plasma Using Diode Array Detection, J. Anal. Methods Chem. 215128 (2015) 1-7.

[23] K. Dunleavy, C.E. Lai, M. Roschewski, J.N. Brudno, B. Widemann, S.Pittaluga, E.S. Jaffe, A.N. Lucas, M. Stetler-Stevenson, C.M. Yuan, P. Harris, D. Cole, J.A. Butman, R.F. Little, L.M. Staudt, H. Wyndham, WilsonPhase I Study of Dose-Adjusted-Teddi-R with Ibrutinib in Untreated and Relapsed/Refractory Primary CNS Lymphoma, Blood 126 (2015) 472-472. 
471 [24] C. Grommes, A. Pastore, I. Gavrilovic I, T. Kaley, C. Nolan, A.M. Omuro, J. Wolfe, E. Pentsova, V. 472 Hatzoglou, I. Mellinghoff, L. DeAngelis, Single-Agent Ibrutinib in Recurrent/Refractory Central 473 Nervous System Lymphoma, Blood 128 (2016) 783-783.

474

475

476

477

478

479

480

481

482

483

484

485

486

487

488

489

490

491

492

493

494

495

496

497

498

499

500

501

502

503

504

505

[25] P. Hubert, J.J. Nguyen-Huu, B. Boulanger, E. Chapuzet, P. Chiap, N. Cohen, P.A. Compagnon, W. Dewé, M. Feinberg, M. Lallier, M. Laurentie, N. Mercier, G. Muzard, C. Nivet, L. Valat, Harmonization of strategies for the validation of quantitative analytical procedures. A SFSTP proposal - Part I. J. Pharm. Biomed. Anal. 36 (2004) 579-586.

[26] P. Hubert, J.J. Nguyen-Huu, B. Boulanger, E. Chapuzet, P. Chiap, N. Cohen, P.A. Compagnon, W. Dewé, M. Feinberg, M. Lallier, M. Laurentie, N. Mercier, G. Muzard, C. Nivet, L. Valat, E. Rozet, Harmonization of strategies for the validation of quantitative analytical procedures. A SFSTP proposal - part II, J. Pharm. Biomed. Anal. 45 (2007) 70-81.

[27] R. Difrancesco, R. DiCenzo, G. Vicente, J. Donnelly, T.M.Martin, L.A. Colon, G. Schifito, G.D. Morse, Determination of lopinavir cerebral spinal fluid and plasma ultrafiltrate concentrations by liquid chromatography coupled to tandem mass spectrometry, J. Pharm. Biomed. Anal. 4 (2007) 1139-1146.

[28] L. Sosvorova, J. Vitku, T. Chlupacova, M. Mohapl, R. Hampl, Determination of seven selected neuro- and immunomodulatory steroids in human cerebrospinal fluid and plasma using LC-MS/MS, Steroids 98 (2015) 1-8.

[29] F. Bai, J. Johnson, F. Wang, L. Yang, A. Broniscer, C.F. Stewart, Determination of vandetanib in human plasma and cerebrospinal fluid by liquid chromatography electrospray ionization tandem mass spectrometry (LC-ESI-MS/MS), J. Chromatogr. B 879 (2011) 2561-2566.

[30] M. Josefsson, M. Roman, E. Skogh, M.L. Dahl, Liquid chromatography/tandem mass spectrometry method for determination of olanzapine and $\mathrm{N}$-desmethylolanzapine in human serum and cerebrospinal fluid, J. Pharm. Biomed. Anal. 53 (2010) 576-82.

[31] X. Yang, G. Li, L. Chen, C. Zhang, X. Wan, J. Xu, Quantitative determination of hederagenin in rat plasma and cerebrospinal fluid by ultra fast liquid chromatography-tandem mass spectrometry method, J. Chromatogr. B 879 (2011) 1973-1979. 
506 [32] P. Voehringer, R. Fuertig, B. Ferger, A novel liquid chromatography/tandem mass spectrometry

507 method for the quantification of glycine as biomarker in brain microdialysis and cerebrospinal fluid 508 samples within 5min, J. Chromatogr. B 939 (2013) 92-97.

509

510 [33] J. Jiang, C.A. James, P. Wong, Bioanalytical method development and validation for the 511 determination of glycine in human cerebrospinal fluid by ion-pair reversed-phase liquid 512 chromatography-tandem mass spectrometry, J. Pharm. Biomed. Anal. 128 (2016) 132-140.

513

514 [34] J. de Jong, D. Skee, P. Hellemans, J. Jiao, R. de Vries, D. Swerts, E. Lawitz, T. Marbury, W. Smith, J. 515 Sukbuntherng, E. Mannaert, Single-dose pharmacokinetics of ibrutinib in subjects with varying 516 degrees of hepatic impairment, Leuk. Lymphoma 58 (2017) 185-194.

517

518 [35] E. Scheers, L. Leclercq, J. de Jong, N. Bode, M. Bockx, A. Laenen, F. Cuyckens, D. Skee, J. Murphy, 519 J. Sukbuntherng, G. Mannens, Absorption, metabolism, and excretion of oral ${ }^{14} \mathrm{C}$ radiolabeled 520 ibrutinib: an open-label, phase I, single-dose study in healthy men, Drug Metab. Dispos. 43 (2015) $521289-297$.

522 
526 Figure 1. Fragmentation patterns of ibrutinib (A) and $\mathrm{PCl}-45227$ (B) with a collision energy of $26 \mathrm{~V}$ and $52731 \mathrm{~V}$, respectively.

Figure 2. Chromatographic separation of ibrutinib and $\mathrm{PCl}-45227$ : total ion chromatogram (A), extracted ion chromatograms : $441.1 \rightarrow 137.9$ (B), $475.1 \rightarrow 304.1$. (C) (concentration of analytes: 199.5

531 ng. $\mathrm{mL}^{-1}$ in blank plasma) RT : retention time in minute.

532

Figure 3. Accuracy profiles of ibrutinib and PCl-45227 in CSF (A) and (B) and in plasma (C) and (D). Accuracy profiles were plotted using a $20 \% \alpha$-risk $(\beta=80 \%)$. Acceptance limits were fixed at $\pm 25 \%$ for the LLOQ and $\pm 15 \%$ for the other QC.

536

537 Figure 4: Chromatograms obtained for double blank, blank spiked at the LLOQ and patient for

538 Ibrutinib and $\mathrm{PCl}-45227$ in both matrices. * : artefact at 2 minutes corresponds to the switch of the 539 divert valve 

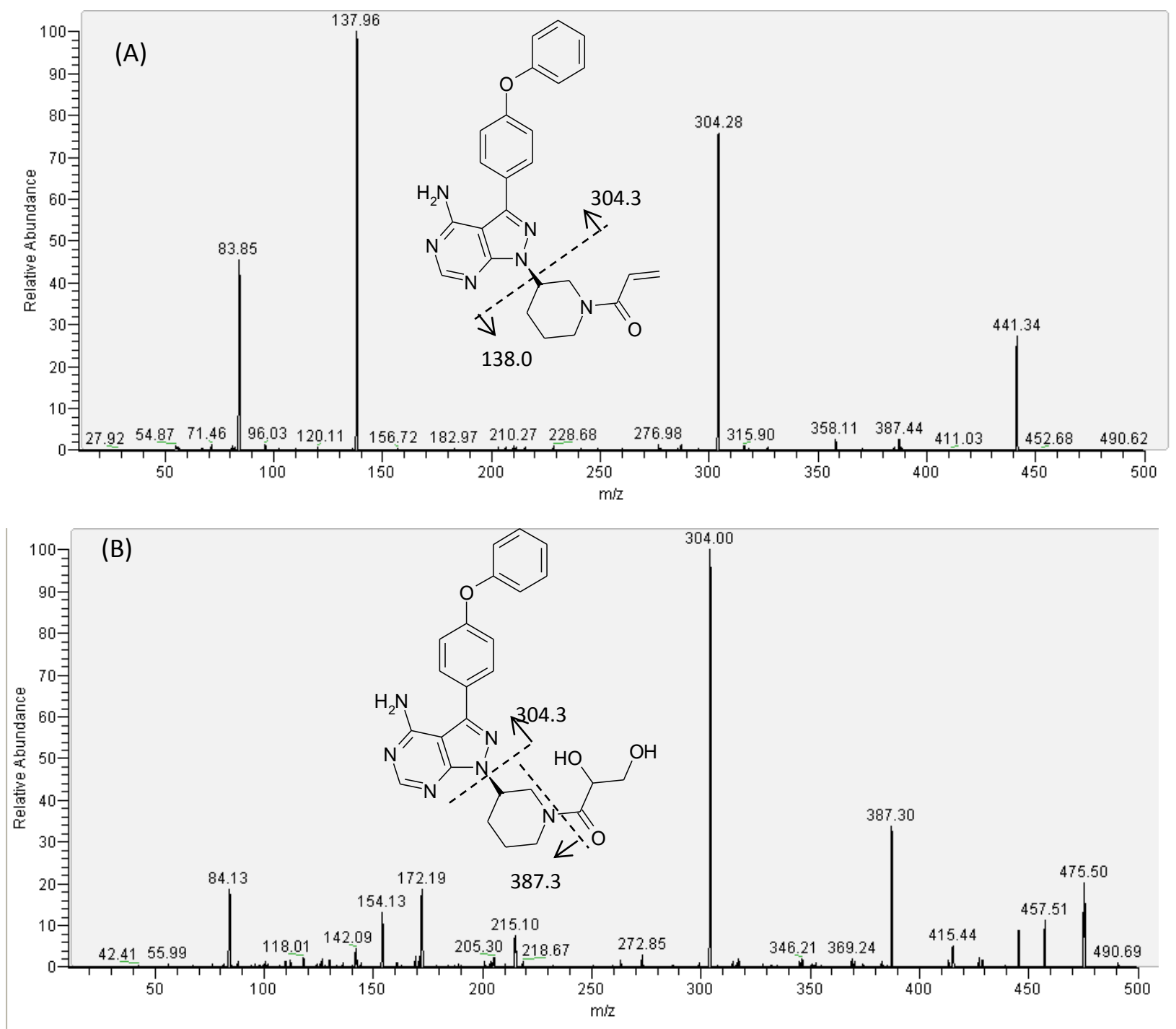
Figure 2

547

548

549

550

551

552

553

554

555

556

557

558
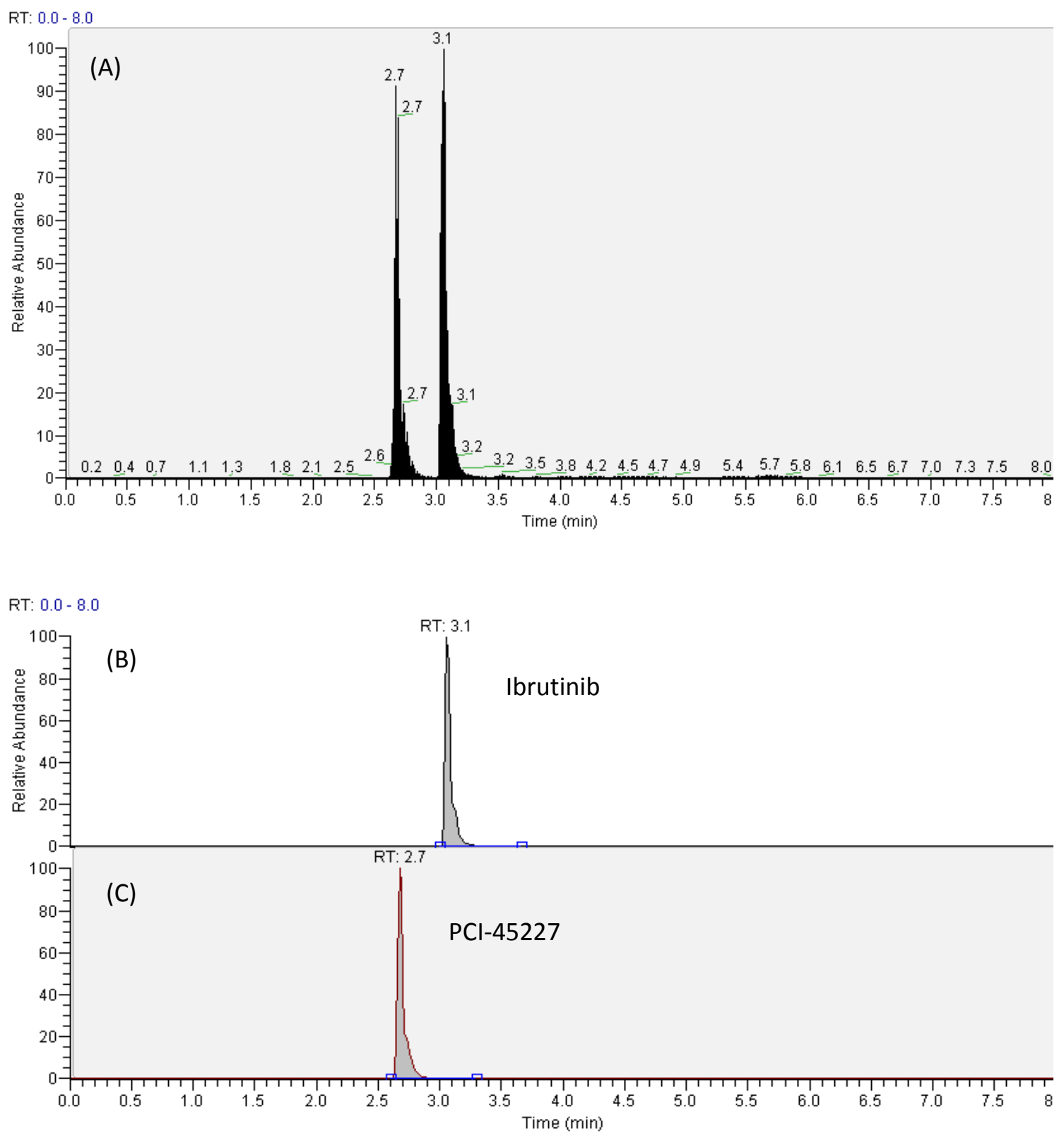
$559 \quad$ Figure 3

560

561

562

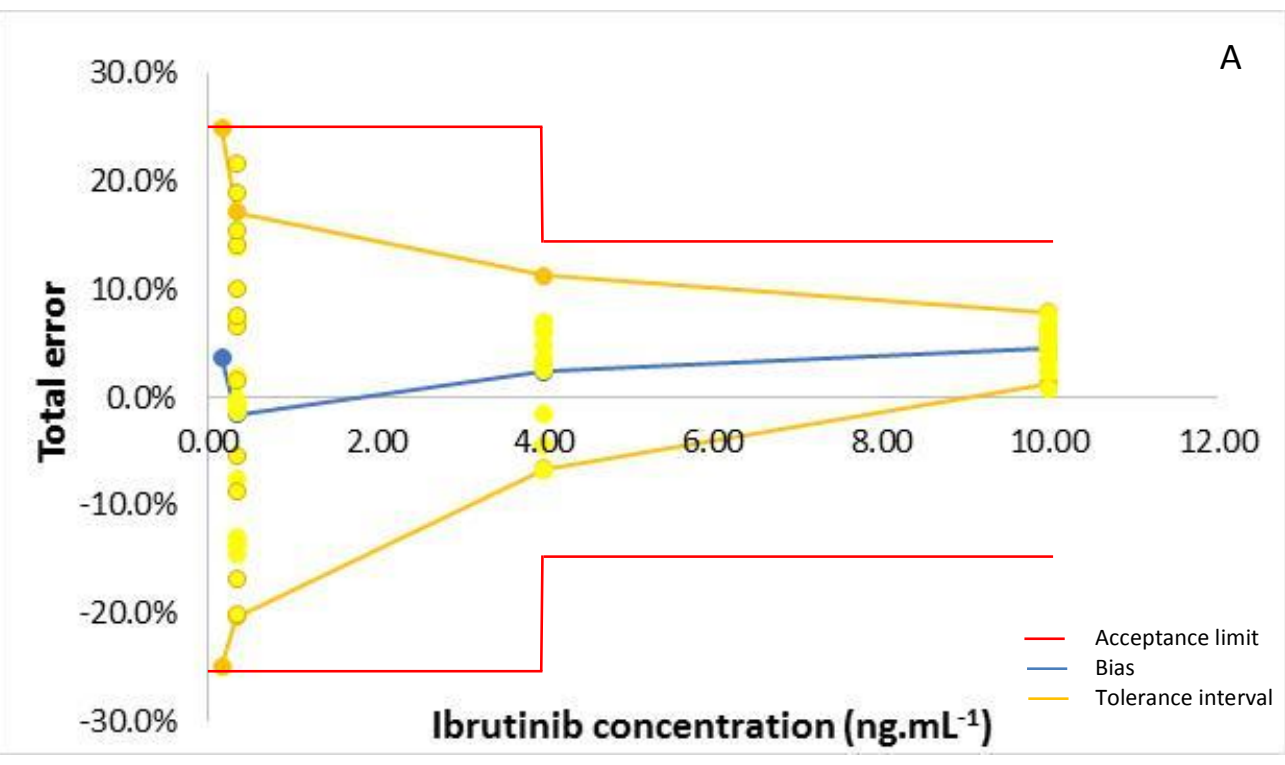

563

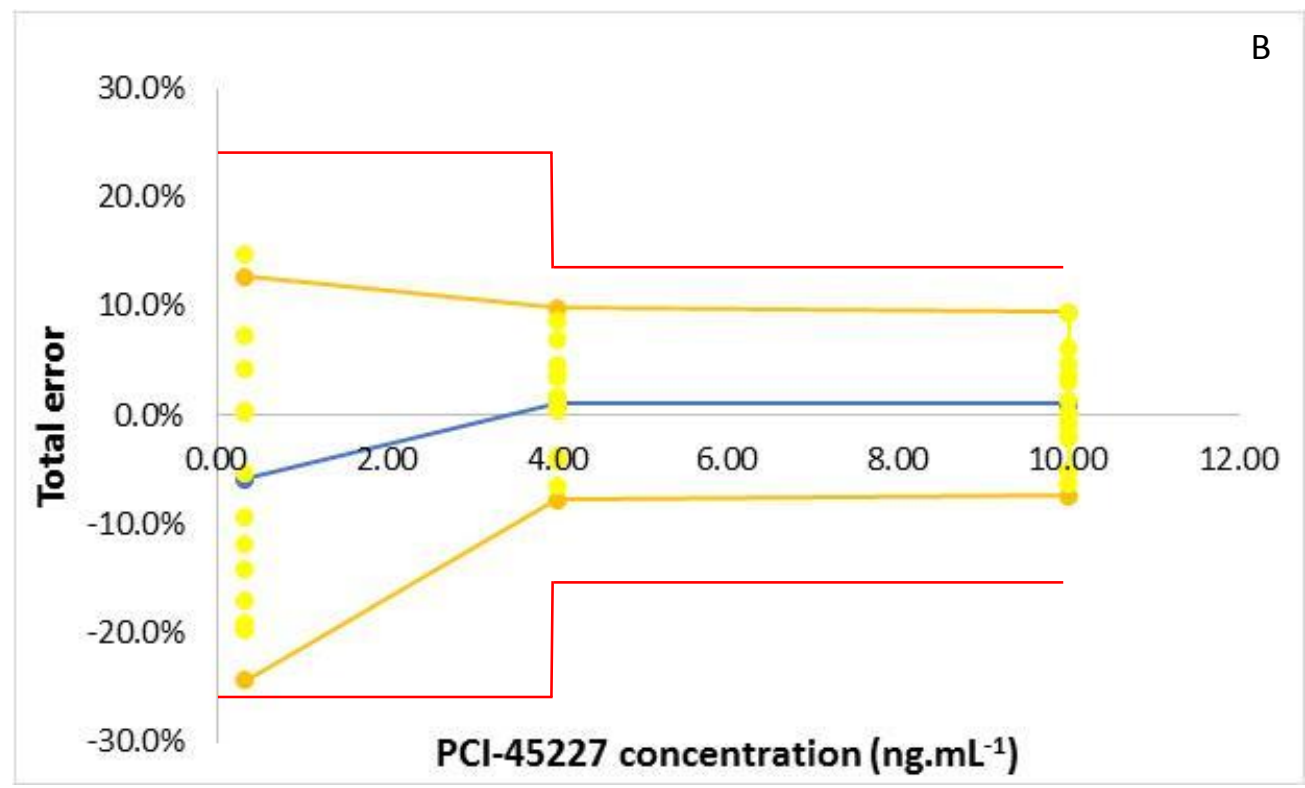

564

565

566

567

568

569

570 

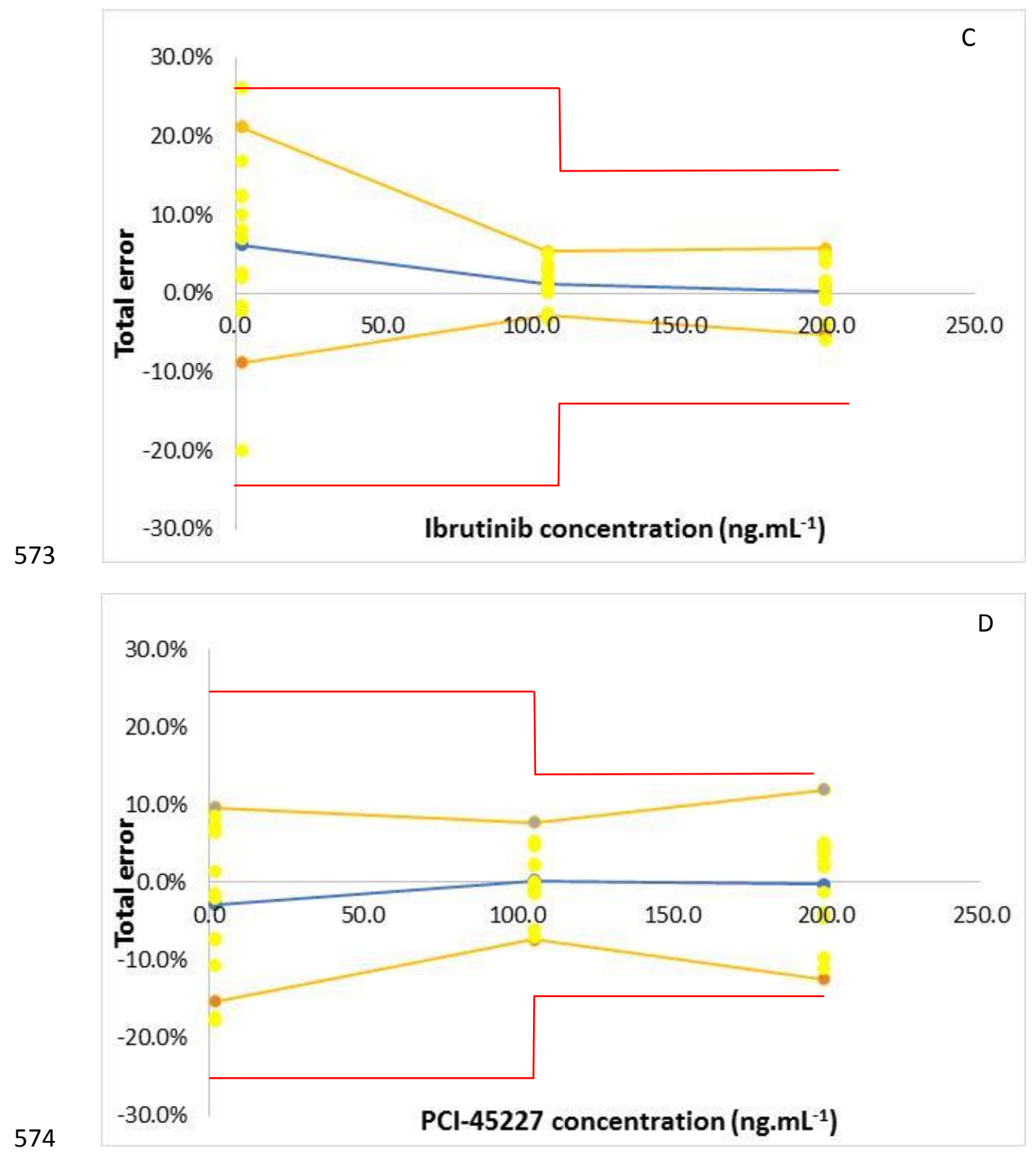

575

576

577

578

579

580

581 


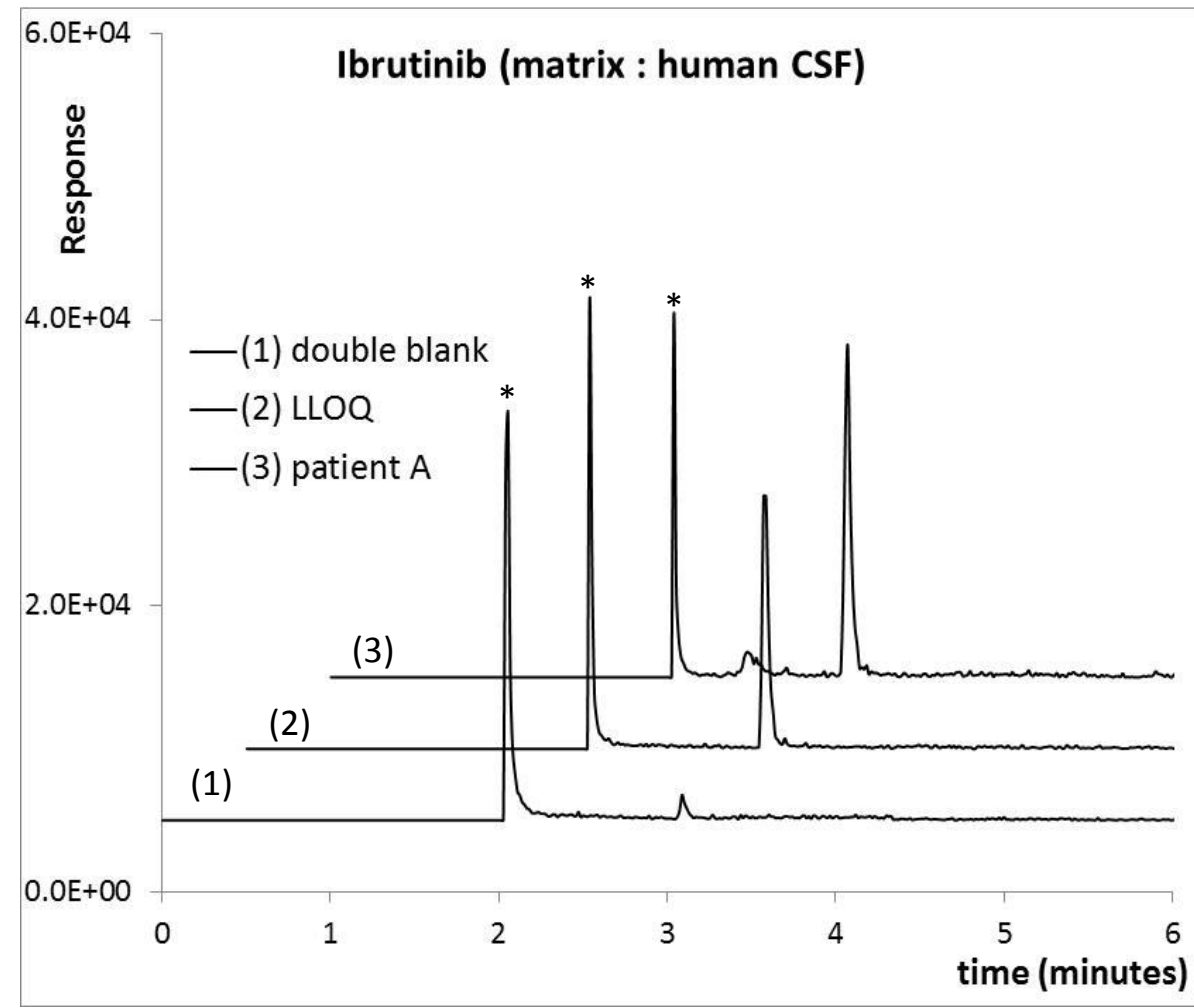

595

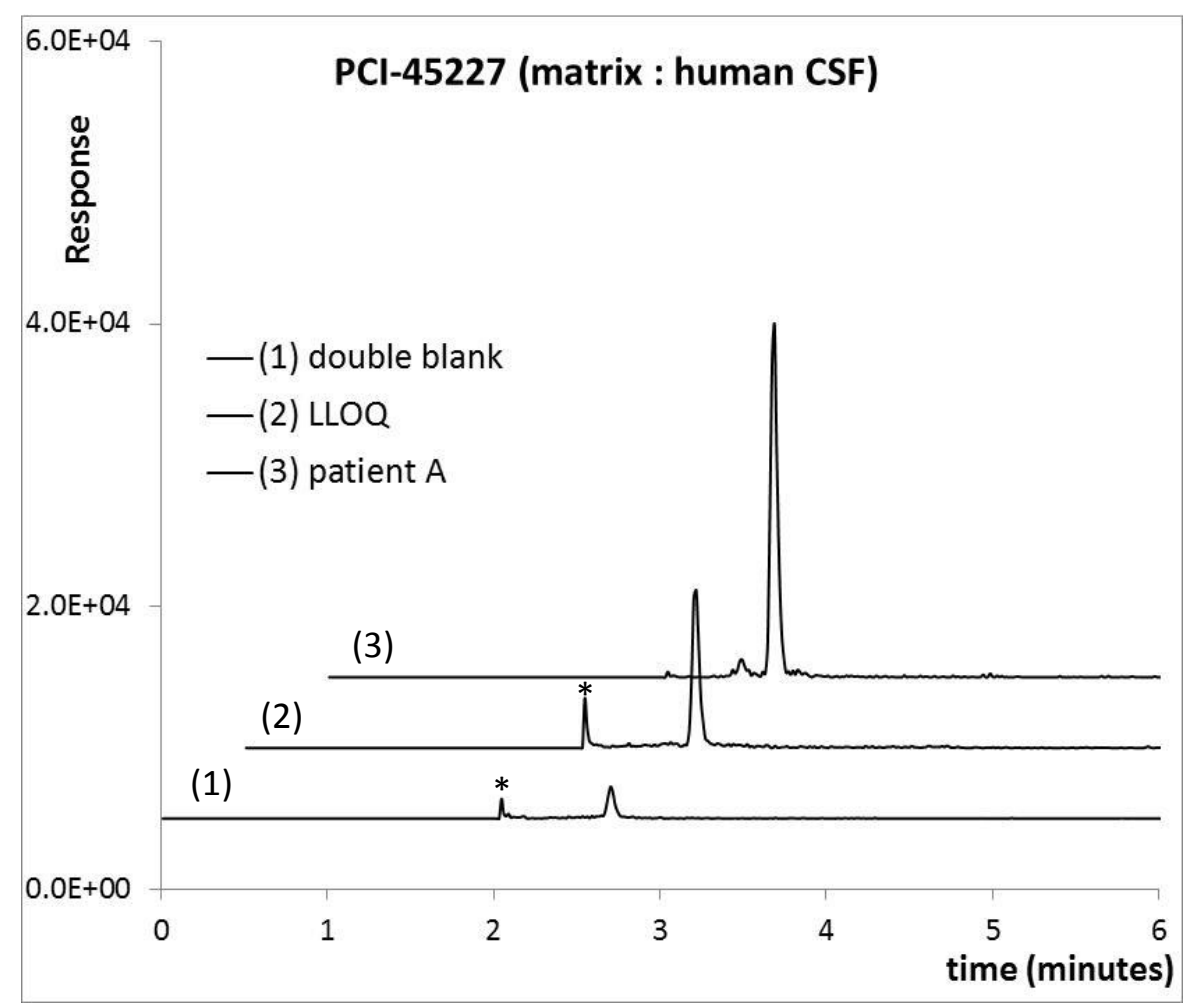




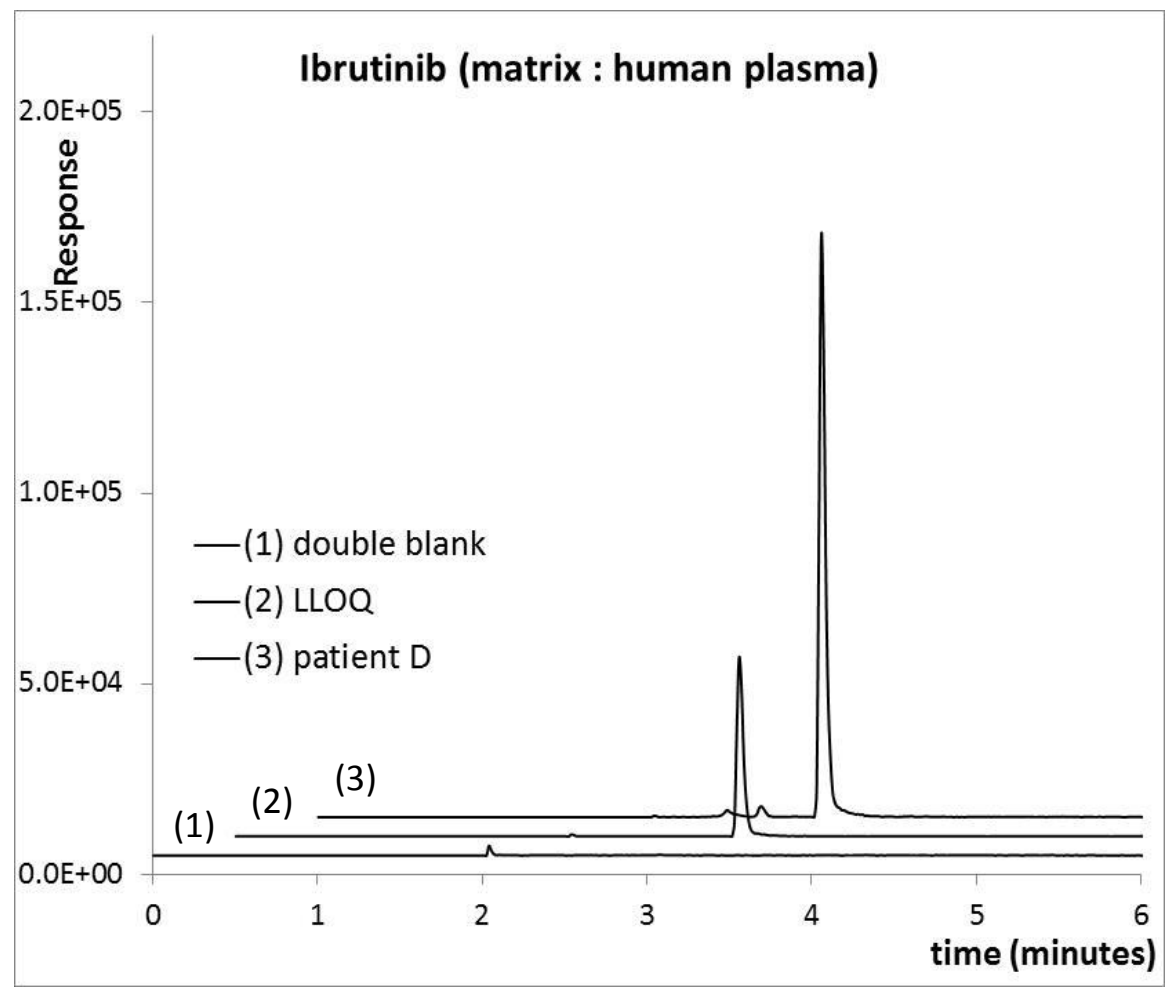

620

621

622

623

624

625

626

627

628

629

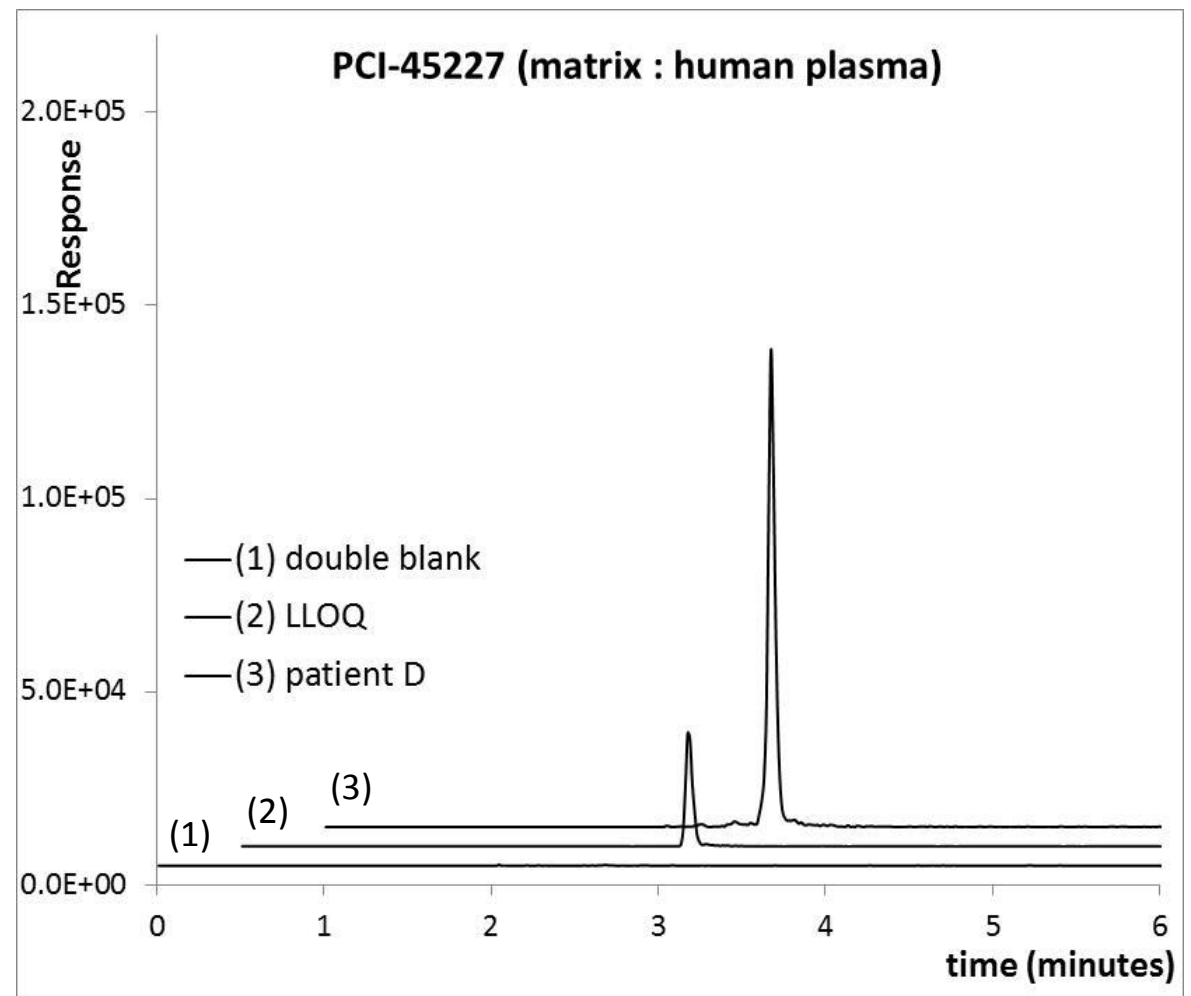


631

\begin{tabular}{|c|c|c|c|c|c|}
\hline \multirow{2}{*}{ Compound } & \multirow{2}{*}{$\begin{array}{c}\text { Precursor ion } \\
\text { mass }(\mathrm{m} / \mathrm{z})\end{array}$} & \multicolumn{2}{|c|}{ Quantification ion } & \multicolumn{2}{|c|}{ Qualification ion } \\
\hline & & mass $(\mathrm{m} / \mathrm{z})$ & $E_{\text {collision }}(V)$ & mass $(\mathrm{m} / \mathrm{z})$ & $E_{\text {collision }}(V)$ \\
\hline ibrutinib & 441.3 & 138.0 & 26 & 304.3 & 29 \\
\hline$\left[{ }^{2} \mathrm{H}_{5}\right]$-ibrutinib & 446.3 & 138.0 & 28 & 309.3 & 26 \\
\hline PCl-45227 & 475.5 & 304.3 & 31 & 387.3 & 24 \\
\hline$\left[{ }^{2} \mathrm{H}_{5}\right]-\mathrm{PCl}-45227$ & 480.5 & 309.3 & 32 & 392.3 & 23 \\
\hline
\end{tabular}

$\mathrm{E}_{\text {collision }}$ : collision energy 
Table 2. Intra-day precision, inter-day precision and relative bias data of the method for quantification of ibrutinib and PCl- 45227 in CSF at the four VS concentrations (low VS 1 , low VS 2 , medium VS and high VS ; concentrations expressed are the concentration in the analyzed solutions)

\begin{tabular}{|c|c|c|c|c|c|c|c|c|c|c|c|}
\hline \multicolumn{3}{|c|}{ Low VS $1: 0.17$ ng. $\mathrm{mL}^{-1}$} & \multicolumn{3}{|c|}{ Low VS $: 0.33 \mathrm{ng} \cdot \mathrm{mL}^{-1}$} & \multicolumn{3}{|c|}{ Medium VS : $4.00 \mathrm{ng} \cdot \mathrm{mL}^{-1}$} & \multicolumn{3}{|c|}{ High VS : 10 ng. $\mathrm{mL}^{-1}$} \\
\hline $\begin{array}{c}\text { Intra-day } \\
\text { precision } \\
\text { (\% RSD) }\end{array}$ & $\begin{array}{c}\text { Inter-day } \\
\text { precision } \\
\text { (\% RSD) }\end{array}$ & $\begin{array}{l}\text { Relative } \\
\text { bias (\%) }\end{array}$ & $\begin{array}{l}\text { Intra-day } \\
\text { precision } \\
\text { (\% RSD) }\end{array}$ & $\begin{array}{c}\text { Inter-day } \\
\text { precision } \\
\text { (\% RSD) }\end{array}$ & $\begin{array}{l}\text { Relative } \\
\text { bias (\%) }\end{array}$ & $\begin{array}{l}\text { Intra-day } \\
\text { precision } \\
\text { (\% RSD) }\end{array}$ & $\begin{array}{c}\text { Inter-day } \\
\text { precision } \\
\text { (\% RSD) }\end{array}$ & $\begin{array}{l}\text { Relative } \\
\text { bias (\%) }\end{array}$ & $\begin{array}{c}\text { Intra-day } \\
\text { precision } \\
\text { (\% RSD) }\end{array}$ & $\begin{array}{l}\text { Inter-day } \\
\text { precision } \\
\text { (\% RSD) }\end{array}$ & $\begin{array}{l}\text { Relative } \\
\text { bias (\%) }\end{array}$ \\
\hline 8.6 & 19.7 & -14.0 & 4.7 & 10.1 & -1.7 & 2.6 & 4.8 & +2.3 & 1.6 & 2.1 & +4.6 \\
\hline 33.3 & 40.1 & 16.0 & 9.4 & 11.9 & -5.8 & 3.4 & 5.2 & +1.1 & 3.4 & 5.0 & +1.1 \\
\hline
\end{tabular}




\begin{tabular}{|c|c|c|c|c|c|c|c|c|c|}
\hline & \multicolumn{3}{|c|}{ Low VS : 2.0 ng. $\mathrm{mL}^{-1}$} & \multicolumn{3}{|c|}{ Medium VS: 105.4 ng. $\mathrm{mL}^{-1}$} & \multicolumn{3}{|c|}{ High VS : 199.5 ng. $\mathrm{mL}^{-1}$} \\
\hline & $\begin{array}{l}\text { Intra-day } \\
\text { precision } \\
\text { (\% RSD) }\end{array}$ & $\begin{array}{l}\text { Inter-day } \\
\text { precision } \\
\text { (\% RSD) }\end{array}$ & $\begin{array}{l}\text { Relative } \\
\text { bias (\%) }\end{array}$ & $\begin{array}{l}\text { Intra-day } \\
\text { precision } \\
\text { (\% RSD) }\end{array}$ & $\begin{array}{l}\text { Inter-day } \\
\text { precision } \\
\text { (\% RSD) }\end{array}$ & $\begin{array}{l}\text { Relative } \\
\text { bias (\%) }\end{array}$ & $\begin{array}{l}\text { Intra-day } \\
\text { precision } \\
\text { (\% RSD) }\end{array}$ & $\begin{array}{l}\text { Inter-day } \\
\text { precision } \\
\text { (\% RSD) }\end{array}$ & $\begin{array}{l}\text { Relative } \\
\text { bias (\%) }\end{array}$ \\
\hline ibrutinib & 10.6 & 10.6 & +6.2 & 2.0 & 2.6 & +1.3 & 2.1 & 3.2 & +0.3 \\
\hline PCl-45227 & 8.8 & 8.8 & -2.8 & 2.8 & 4.4 & +0.2 & 2.7 & 6.6 & -0.2 \\
\hline
\end{tabular}

Table 3. Intra-day precision, inter-day precision and relative bias data of the method for quantification of ibrutinib and PCl- 45227 in plasma at the three $\mathrm{VS}$ concentrations (low VS, medium VS and high VS; concentrations expressed are the concentration in the analyzed solutions)) 
645

\begin{tabular}{ccc}
\cline { 2 - 3 } & $\begin{array}{c}\text { [ibrutinib] } \\
\text { ng. } \mathrm{mL}^{-1}\end{array}$ & $\begin{array}{c}{[\mathrm{PCl}-45227]} \\
\mathrm{ng} \cdot \mathrm{mL}^{-1}\end{array}$ \\
\hline CSF samples & & \\
Patient A & 0.59 & 1.45 \\
Patient B & 0.85 & 5.06 \\
Patient C & 2.95 & 9.73 \\
\hline Plasmatic samples & & 20.90 \\
Patient D & 19.44 & 47.89 \\
Patient E & 7.27 & 12.00 \\
Patient F & 6.61 & \\
\hline
\end{tabular}

646 